\title{
Why Czechs and Turks?
}

"Do you like the Turks? Do you like those heathen dogs? You don't, do you?" the Good Soldier Švejk says to Palivec, the innkeeper, in Jaroslav Hašek's famous novel. Palivec replies: "One customer is as good as another, never mind a Turk. For tradesmen like us politics doesn't enter into it. Pay your beer, sit down in my pub and jabber what you like. That's my principle. It's all the same to me whether our Ferdinand was done in by a Serb or Turk, Catholic or Moslem, anarchist or Young Czech." The views that Švejk and Palivec express here are reflective of the ways many Czechs felt about the Turks in the first decades of the 2oth century. But Švejk's words are particularly significant because, love him or hate him, the amiable, servile "idiot” Švejk is Czech literature's most emblematic figure and for many the embodiment of the Czech national character. That Hašek even mentions the Turks in his brilliant anti-war novel and has Švejk voice strong anti-Turkish sentiments therefore demands an explanation. And that is what this book tries to do: explain why the Turks remained a persistent and often quite prominent image in early-2oth-century Czech society, which for generations had had little direct contact with the Ottoman Empire and its inhabitants. For although it was not only in times and places of conflict that Europeans turned their attention to the Turks, direct contact with the Ottoman Empire naturally increased the level of interest in Turkish themes.

Between the 14th and 17th centuries the battlefields on which European armies clashed with the usually victorious Ottomans moved from Southeastern Europe to the regions controlled by the Italian states, and from there to Central Europe and further East. In the aftermath of these conflicts large areas of Southern, Eastern and Central Europe came under Ottoman rule. The Ottoman army was still able to threaten Vienna in 1683, but Ottoman power then started to recede, and only the Southeast of Europe remained in Ottoman hands. Another important watershed in Europeans' relations with the Ottoman Empire and their interest in the Middle East was Napoleon's invasion of Egypt in 1798. By the early 19th century, the Ottoman army was no longer a threat to the modern states of Europe, and despite the Ottoman Empire's attempts to reform itself, the balance of power between the former rivals shifted to Europe's advantage. The Ottoman army continued to wage war, but its major

1 Jaroslav Hašek, The Good Soldier Švejk and His Fortunes in the World War, trans. Cecil Parrott (London: Penguin Books, 1973), 9.

(C) JITKA MALEČKOVÁ AND CHARLES UNIVERSity, FACULTY OF ARTS, 
rival was now Russia, and in the mid-19th century Western states went so far as to support the Ottoman Empire militarily in a war against Russia. In the decades that followed, the Ottoman army was involved in further armed conflicts, including the Russo-Turkish war of $1877-1878$, the war with Italy over Tripoli in 1911-1912 and the Balkan Wars in 1912-1913. Even when not at war, the government had to face rebellions and protests from discontented segments of the population in the empire, sometimes instigated or supported from the outside, especially by Russia, often exploited by European statesmen, and always closely followed and debated by the European public. At the same time, the Ottoman Empire grew closer to Europe in areas of the economy, trade, diplomacy, and culture, and in the way of life among the elites in Istanbul. Accompanying these developments was that the Ottoman government became increasingly dependent on the help and capital of European powers, just as the struggle between these powers for influence in the empire and for its territory was starting to accelerate. Modernization continued, and in some respects culminated, under Sultan Abdülhamid II (1876-1909), whose reign coincided with a large part of the period that this book is concerned with, even though by contemporaries his rule was considered the epitome of autocracy and tyranny. ${ }^{2}$ In the empire, the opposition movement, spearheaded by Ottoman intellectuals, spread at the turn of the century through the ranks of army officers and some bureaucrats and resulted in the Young Turk Revolution in $1908 .^{3}$ The Young Turk government established after the revolution allied itself with the Central Powers and brought the Ottoman Empire into World War I, which precipitated the dissolution of the empire.

The Ottoman Turks were for centuries viewed as a major threat to Europe and "the souls of Europeans." They were also a source of fascination and figured centrally in European perceptions of "the Other." Turkish themes have abounded in European literature, art, and thinking. They can even be found in countries that are separated from the Turks by an ocean. ${ }^{4}$ Earlier scholarship has tended to argue that a fairly uniform image of "the Turk" held sway across Europe and has highlighted how from the late middle ages the Turks were

2 On the rule of Abdülhamid II see Benjamin C. Fortna, "The Reign of Abdülhamid II," in The Cambridge History of Turkey, ed. I. Metin Kunt, vol. 4, Turkey in the Modern World, ed. Reşat Kasaba (Cambridge: Cambridge University Press, 2008), 38-61.

3 On the Young Turks see M. Şükrü Hanioğlu, The Young Turks in Opposition (New York: Oxford University Press, 1995); Stefano Taglia, Intellectuals and Reform in the Ottoman Empire: The Young Turks on the Challenges of Modernity (London: Routledge, 2017).

4 See Justin McCarthy, The Turk in America: Creation of an Enduring Prejudice (Salt Lake City: University of Utah Press, 2010). 
regarded as the enemy of Christendom. ${ }^{5}$ This opinion has been challenged by more recent scholars, who see variety in the views of the Turks that existed around Europe at any given time and place, ${ }^{6}$ and there is moreover an increasing awareness among historians today that the Ottoman Empire was also a part of Europe, and not merely its foe. ${ }^{7}$ How the Turks were portrayed and what image of them prevailed was affected by various factors, such as particular power relations or whether or not Europe was at war with the Ottoman Empire at the time, and in areas controlled by the Turks these images also responded to the Turks' position as rulers and oppressors.

The imagery further reflected a fear of and a curiosity about religious and cultural difference. Islam and the Ottoman Turks occupied an important place in the discourses of the Reformation and the Counter-Reformation. But religious animosity was not the only lens through which the Turks were viewed. The humanist historians in the Italian states that were threatened by Ottoman military power in the $15^{\text {th }}$ century were driven by political considerations when, in their shock at the fall of Constantinople in 1453, they tried to find an explanation for the Ottomans' success by studying Ottoman history. ${ }^{8}$ In the 16th century, when Ottoman power and expansion on European territory culminated, the Turks were not only viewed with fear but also with a sense of awe; this sentiment was expressed in the epithet Magnifique or "Magnificent" that was used in Europe to refer to Sultan Süleyman (called Kanuni, "The Lawgiver," by the Ottomans), who embodied Ottoman glory at its peak. Even in the border regions between Christendom and Islam, the relationships and interactions between the rulers and inhabitants of the Ottoman and Holy Roman Empires were very diverse, as Charlotte Colding Smith, among others, has shown using manifold forms of depictions and descriptions of Ottoman Turks that existed

5 See, e.g., Robert Schwoebel, The Shadow of the Crescent: The Renaissance Image of the Turk (1453-1517) (Niewkoop: B. De Graaf, 1967); Richard William Southern, Western Views of Islam in the Middle Ages (Cambridge, MA: Harvard University Press, 1962).

6 James G. Harper, "Introduction," in The Turk and Islam in the Western Eye, 1450-1750, ed. James G. Harper (Farnham: Ashgate, 2011), 1; Nancy Bisaha, Creating East and West: Renaissance Humanists and the Ottoman Turks (Philadelphia: University of Pennsylvania Press, 2004), 6ff.; David R. Blanks and Michael Frassetto, "Introduction," in Western Views of Islam in Medieval and Early Modern Europe: Perception of Other, ed. David R. Blanks and Michael Frassetto (New York: St Martin's Press, 1999), 2.

7 See, e.g., Virginia H. Aksan and Daniel Goffman, eds., The Early Modern Ottomans: Remapping the Empire (Cambridge: Cambridge University Press, 2007); Pascal Firges et al., eds., Well-Connected Domains: Towards an Entangled Ottoman History (Leiden: Brill, 2014).

8 Margaret Meserve, Empires of Islam in Renaissance Historical Thought (Cambridge, MA: Harvard University Press, 2008), 3-4. 
in the 15th and 16th centuries. ${ }^{9}$ This imagery could also serve various symbolic functions. Ivan Kalmar, for example, interprets the 17 th-century depiction of Turks as savants on the astronomical clock in Prague as symbolizing the futility of knowledge when unaccompanied by Christian faith: "If you have worldly wisdom, but not the Holy Faith, then you might as well be a Turk."10

It has long been established that the European perception of Ottoman rule as despotic, ajudgment that began to be even more salient in European thought in the 17th and then especially in the 18th century, played an instrumental role in the debates on European political institutions at that time, which included conceptions of Enlightened despotism..$^{11}$ The European debate on Oriental despotism was moreover in reality directed at Europe itself, while the Orient mostly figured in it just rhetorically. ${ }^{12}$ Larry Wolff has argued that in the long 18 th century, from the 168 os to the 1820 s, when the Ottoman Empire was no longer viewed primarily in religious terms and was not yet being looked on as the "Sick Man of Europe," it "inspired a balance of fear, interest, curiosity, titillation, entertainment, and even sympathy." This made "the Turk" an appealing character to introduce into European opera, "through which Europeans explored what it meant to be European."13 Wolff illustrates the seemingly obvious, but often overlooked fact that France's experience with the Ottoman Turks was very different from that of Venice and the Habsburg Monarchy, the Ottoman Empire's traditional military foes. As a result, they had an entirely distinct attitude toward the Turks, and this was reflected even in opera. ${ }^{14}$

Images of the Turks in any given country were linked to the specific situation in that country. Thus, despite the strong influence of Enlightenment notions of

9 Charlotte Colding Smith, Images of Islam, 1453-16oo: Turks in Germany and Central Europe (London: Pickering and Chatto, 2014), 2ff.

10 Ivan Kalmar, "The Turks of Prague:The Mundane and the Sublime," in Orient-OrientalistikOrientalismus: Geschichte und Aktualität einer Debatte, ed. Burkhard Schnepel, Gunnar Brands, and Hanne Schönig (Bielefeld: Transcript Verlag, 2011), 272. In his book on early Orientalism, Kalmar argues that "the Orient illustrates man's inability or unwillingness to recognize the presence of God in the world." Ivan Kalmar, Early Orientalism: Imagined Islam and the Notion of Sublime Power (New York: Routledge, 2012), 44.

11 Michael Curtis, Orientalism and Islam: European Thinkers on Oriental Despotism in the Middle East and India (Cambridge: Cambridge University Press, 2009), 51-71. See also Alain Grosrichard, The Sultan's Court: European Fantasies of the East, trans. Liz Heron (London: Verso, 1998), 26-50.

12 Joan-Pau Rubiés, "Oriental Despotism and European Orientalism: Botero to Montesquieu," Journal of Early Modern History 9, no. 1-2 (February 2005): 111.

13 Larry Wolff, The Singing Turk: Ottoman Power and Operatic Emotions on the European Stage from the Siege of Vienna to the Age of Napoleon (Stanford: Stanford University Press, 2016), 2.

14 Wolff, The Singing Turk, 4. 
Oriental despotism that to a certain degree unified the European perception of the Ottoman Empire, the ways the Turks were viewed around Europe continued to vary. The best-known and most studied opinions on the Turks in the modern period were those of the French and British, and generalizations about the "European" relationship to the Turks are therefore based on the views of two countries for whom, incidentally, the Ottoman Empire was never a major foe or mortal danger. ${ }^{15}$ Unlike the French and the British, who were further away, the people who lived under Ottoman rule or in the border areas that were for centuries the stage of fighting between the Ottoman and Habsburg Empires saw the Turks as a more imminent threat. In a richly documented account of Habsburg-Ottoman relations and of views on the Turks in Germanspeaking Central Europe between the 16th and 19th centuries, Paula Sutter Fichtner highlighted the Austrian population's extremely hostile opinion of the Turks. This dislike affects even the author herself, who declares to have written her book as a warning to those "who wish at all times to communicate productively with dangerous, persistent and abidingly distasteful enemies."16 The prevalence of negative attitudes toward the Turks in the Austrian regions is similarly revealed in the work of Andre Gingrich, which offers a critical perspective on modern Austrian opinions about the Turks and the Muslims of Bosnia. ${ }^{17}$ The Ottoman Turks were also viewed as the enemy by Southeast Europeans, who were living under Ottoman rule or in fear of it. But even among the Southern Slavs the images of the Turks were more diverse. They did not just allude to the "Turkish yoke," but reflected also a more positive relationship with the Ottoman Turks, especially among the Muslim population. ${ }^{18}$

15 See Aslı Çırakman, From the "Terror of the World" to the "Sick Man of Europe:" European Images of Ottoman Empire and Society from the Sixteenth Century to the Nineteenth (New York: Peter Lang, 2002);Christoph Bode, ed., West Meets East:Klassikerder britischen OrientReiseliteratur (Heidelberg: Universitätsverlag Karl Winter, 1997); Rana Kabbani, Europe's Myths of Orient (Bloomington: Indiana University Press, 1986); Edward W. Said, Orientalism (New York: Vintage Books, 1979).

16 Paula Sutter Fichtner, Terror and Toleration: The Habsburg Empire Confronts Islam, 15261850 (London: Reaktion Books, 2008), 71.

17 Andre Gingrich, "Frontier Myths of Orientalism: The Muslim World in Public and Popular Cultures of Central Europe," in Mediterranean Ethnological Summer School, ed. Bojan Baskar and Borut Brumen (Ljubljana: Inštitut za multikulturne raziskave, 1998), 2:99-128; Andre Gingrich, "Blame It on the Turks: Language Regimes and the Culture of Frontier Orientalism in Eastern Austria," in Diskurs - Politik - Identität / Discourse - Politics Identity, ed. R. De Cillia et al. (Tübingen: Stauffenburg, 2010), 71-81; Andre Gingrich, "The Nearby Frontier: Structural Analyses of Myths of Orientalism," Diogenes 6o, no. 2 (2015): $60-66$.

18 See Srđan M. Jovanović, "The Ottoman Empire as Friend and Foe: Perceptions of Ottoman Rule in Serbia and Bosnia and Thereupon Based Nationalisms," Review of Social Studies 4, 
The Czechs were never under Ottoman rule. Yet, the wars with the Ottoman Empire had a significant impact on Czech history: "the Turkish threat" helped propel Ferdinand of Habsburg onto the Czech throne in 1526, making the Czech lands part of the Habsburg Empire, whose ruling dynasty cast itself as the defender of Christianity against Islam. The Turks thus at that time became a relevant Other in the eyes of the Czechs and the influence of the wars continued to shape Czechs' attitudes toward the Turks into the modern era. ${ }^{19}$ There was no single "Czech image of the Turks" in the early modern period, as Tomás Rataj and, more recently, Laura Lisy-Wagner have shown. ${ }^{20}$ According to LisyWagner, the introduction of "the Turk" into the early modern construction of Czechness destabilized the German/Czech dichotomy. ${ }^{21}$ Early modern Czechs used the Turkish subject to establish a place for themselves within or in relation to Europe, and their views on the Turks were affected by their ambivalent relationship to Catholic Habsburg rule and to the Germans. By the 19th century, the Turks were no longer an immediate concern for the Czechs, but "the Turk" remained present in Czech public discourse and notions about the Turks were expressed in travel writing, scholarship, and journalism, as well as in literature and the arts. Nevertheless, Czech opinions on the Turks in the modern era have been left largely unexplored. While Czech scholars have dealt with Czech attitudes toward Islam and the Middle East more generally, ${ }^{22}$

no. 1 (Spring 2017): 71-89; Božidar Jezernik, "Imagining 'the Turk," in Imagining "the Turk," ed. Božidar Jezernik (Cambridge: Cambridge Scholars Publishing, 2010), 1-16.

19 Early modern Czech perceptions of the Turks have received correspondingly detailed attention by scholars. See, e.g., Zdeňka Tichá, Jak stařr Čechové poznávali svět (Prague: Vyšehrad, 1985); Josef Kunský, Čeští cestovatelé, 2 vols. (Prague: Orbis, 1961); Tomáš Rataj, "Obraz Turka v české renesanční společnosti ve světle cestopisné literatury," Folia Historica Bohemica 17 (1994): 59-83; Jiří Hrubeš and Josef Polišenský, "Turecká otázka, uherská povstání a veřejné mínění předbělohorských Čech," Historický časopis 7, no. 1 (1959): 74103; Eduard Petrů, "Das Bild der Türkei in Reisebeschreibungen des 16. Jahrhunderts," in Studien zum Humanismus in den böhmischen Ländern, ed. Hans-Bernd Harder et al., vol. 3, Die Bedeutung der humanistischen Topographien und Reisebeschreibungen in der Kultur der böhmischen Länder bis zur Zeit Balbíns, ed. Hans-Bernd Harder et al. (Cologne: Böhlau, 1993). Another line of research deals with the Turks in the context of Czech relations with other Slavs and the Balkan countries. For an older but rather comprehensive overview of these relations see Václav Žáček et al., Češi a Jihoslovanév minulosti: Od nejstarších dob do roku 1918 (Prague: Academia, 1975); Růžena Havránková, “Česká veřejnost na pomoc protitureckým povstáním jižních Slovanů," Slovanské historické studie 6 (1966): 5-53.

20 Tomáš Rataj, České země ve stínu půlměsíce: Obraz Turka v raně novověké literatuře z českých zemí (Prague: Scriptorium, 2002); Laura Lisy-Wagner, Islam, Christianity and the Making of Czech Identity, 1453-1683 (Burlington, VT: Ashgate, 2013).

21 Lisy-Wagner, Islam, Christianity and the Making of Czech Identity, 171.

22 See, e.g., Miloš Mendel, Bronislav Ostřanský, and Tomáš Rataj, Islám v srdci Evropy: Vlivy islámské civilizace na dějiny a současnost českých zemí (Prague: Academia, 2007). 
mainstream Czech historiography tends to avoid uncomfortable questions, such as those that touch on Czech Orientalism or colonial ambitions. Notable exceptions can be found mainly in the works of the younger generation of scholars, who have studied, for instance, Czech travelers to the Middle East and Czech images of Egypt and the Balkan Slavs. ${ }^{23}$

This book examines Czechs' views of the Turks in the last half century of the existence of the Ottoman Empire, from the 1870s, marked by uprisings in the Ottoman Balkans that were closely watched by the Czechs, up to 1923, when the Turkish Republic was founded. ${ }^{24}$ The establishment of an independent Czechoslovak state in 1918 was a major turning point in Czech history, and immediately after the emergence of the Czechoslovak Republic interest in foreign countries, including all things Turkish, temporarily decreased. Writings about the Turks that appeared between 1918 and 1923 drew on knowledge, travels, and stereotypes from an earlier period and reflected the reality of the time in which the Ottoman Empire existed. In this sense, 1923 was a more important watershed than 1918. The book asks what motivated Czechs at the turn of the century to take an interest in the Turks and their country. The relatively long period covered here has been chosen so that it is possible to examine whether one hegemonic stereotype of the Turks survived from earlier times, or whether diverse views existed in parallel to each other, not all of which were necessarily based on the binary opposition between the Czechs and the Turks. Is it possible to identify a specific "Czech" perception of the Turks, or, to put it differently, how did the views of the Turks reflect the fact that they were produced by Czechs, citizens of the Austro-Hungarian Empire, and members of a Central European nation struggling for national rights?

23 Lucie Storchová, ed., "Mezi houfy lotrưv se pustiti...": České cestopisy o Egyptě 15.-17. století (Prague: Set out, 2005); Adéla Jůnová Macková et al., "Krásný, báječný, neštastný Egypt!" Čeští cestovatelé konce 19. a první poloviny 20. století (Prague: Libri, 2009). See also several chapters in the conference-based edited volume, Kateřina Piorecká and Václav Petrbok, eds., Cizí, jiné, exotické v české kultuře 19. století: Sborník př́spěvků z 27. ročníku sympozia k problematice 19. století; Plzeň, 22.-24. února 2007 (Prague: Academia, 2008); Hana Navrátilová, Egypt v české kultuře přelomu devatenáctého a dvacátého století (Prague: Set out, 2001); František Šístek, Junáci, horalé a lenoši: Obraz Černé Hory a Černohorců v české společnosti, 1830-2006 (Prague: Historický ústav, 2011).

24 This book does not deal with the history of Czech relations with the Balkans. For this history see Žáček et al., Češi a Jihoslované v minulosti; Šístek, Junáci, horalé a lenoši; Miroslav Šesták et al., Dějiny jihoslovanských zemí, 2nd ed. (Prague: Nakladatelství Lidové noviny, 2009); Ladislav Hladký et al., Vztahy Čechů s národy a zeměmi jihovýchodní Evropy / Relations between Czechs and the Nations and Countries of Southeastern Europe (Prague: Historický ústav, 2010); Ladislav Hladký et al., eds., České a slovenské odborné práce o jihovýchodni Evropè: Bibliografie za léta 1991-200o / Czech and Slovak Scholarly Works on Southeast Europe: Bibliography from 1991-200o (Brno: Masarykova univerzita, 2003). 
Over the course of the period analyzed here and especially in the late 19th century, the meaning and uses of the terms "Czech" and "Turk" were not selfevident, or at least they were less clear than they are today. The complicated history of both terms cannot be given justice in a brief note and has already been described elsewhere, ${ }^{25}$ but a word of explanation is necessary at this point. Whose views on whom are we inquiring into? For centuries, Ottoman Turks identified primarily with the Ottoman Empire's ruling dynasty and Islam, although other allegiances existed as well. Only in the late 19th century did the educated Ottoman-Turkish elites start to reflect on their "Turkishness," of which they had been previously aware, but which only became significant at the turn of the century and especially after the Young Turk Revolution of 1908. And it was even later, after World War I and the formation of the Turkish Republic, that Turkish identity became more widespread. "Turk" was a term that Western authors used to refer not just to the Ottoman Turks, but also to other Muslims in the Ottoman Empire, and occasionally to Muslims who were not even the subjects of that Empire. Conversely, both "Muslim" and "Ottoman" were used to denote a Turk. ${ }^{26}$ The terminology was not consistent and in some European languages usage oscillated also between words with different connotations. The Czechs, like other Europeans, called the Muslims of the Ottoman Empire "Turks" (Turci), but they used also other terms, as the chapters below will show. The book marginally refers to Muslims more generally and to other ethnic groups of the Ottoman Empire but focuses on Czechs' views of the Ottoman Turks and those who were called Turks in Bosnia-Herzegovina. ${ }^{27}$

"Czechness" is not much easier to define than "Turkishness," although the percentage of the population of the Czech lands who by the 1870 s identified as Czechs was immeasurably greater than the level of Turkish identification

25 For a concise overview of the emergence of Turkish nationalism see David Kushner, The Rise of Turkish Nationalism, 1876-19o8 (London: Frank Cass, 1977); on more recent perspectives on Turkish nationalism and its history see Modern Türkiye'de Siyasi Düşünce, vol. 4, Milliyetçilik, ed. Tanil Bora and Murat Gültekingil (Istanbul: İletişim, 2008). For the Czech case see Jeremy King, Budweisers into Czechs and Germans: A Local History of Bohemian Politics, 1848-1948 (Princeton, NJ: Princeton University Press, 2005).

26 The Turks themselves were slow to adopt the denomination Turk. On the ethnonyms of the Turks see Kushner, Turkish Nationalism, 20-26; see also Mehmet Kalpakl,, "Turk and Ottoman: A Brief Introduction to Their Images in the Ottoman Empire," in Historical Image of the Turk in Europe: 15th Century to the Present; Political and Civilisational Aspects, ed. Mustafa Soykut (Istanbul: The ISIS Press, 2003), 13-18.

27 The inconsistency of the sources is reflected in the terminology applied in their interpretation: "Turks" appear even where "Ottomans" or "Ottoman Turks" and occasionally "Muslims" might be more precise, but effort has been made to make the meaning clear from the context. 
among Ottoman Turks. Scholars have often too easily attributed Czechness to those for whom ethnic identity was either not very relevant or whose identification could even change depending on the situation and the perceived advantages to this identification. Many Czechs and the Germans who lived in the Czech lands and at their borders (or perhaps more precisely many Czechspeakers and German-speakers ${ }^{28}$ ) were throughout the 19th century flexible about their national belonging, as Tara Zahra has convincingly demonstrated. ${ }^{29}$ Speaking about "Czech" views is thus a generalization employed to avoid qualifying the word each time it appears. While this book analyzes works written in Czech by "Czechs," it does not suggest that everybody who wrote in Czech was deeply concerned with his or her Czech identity. Most Czechs, including the authors mentioned in this book, were loyal subjects of the Habsburg Empire and some did not identify solely as Czechs, although intellectual elites tended to consider national belonging important and often worked tirelessly to spread and strengthen their compatriots' allegiance to the Czech nation. In the book, "Czech" refers to views expressed by authors who wrote in Czech on Turkish themes and whose works, each in its own idiosyncratic way, integrated the Turks into modern Czech culture, especially educational non-fiction.

Given the position of the Czech population within the Habsburg Empire, mainstream Czech attitudes toward the Turks in the late 19th and early 2oth centuries will necessarily diverge at least somewhat from the prevailing outlook of both the imperial powers, including the views of the German-speaking Austrian elites, ${ }^{30}$ and the peoples who experienced direct Ottoman rule. Czechs' views were shaped not just by the early modern "Turkish wars," the armed conflicts that occurred between Christian Europe and the Ottoman Empire, but also by the location of the Czech lands. The territory inhabited by the Czech population did not, for the most part, neighbor on the Ottoman Empire, but at the same time Czechs were not so remote from Ottoman Turks as to pay no attention to them at all. It is my contention that Czechs' views of the Turks are illuminative not despite the relative distance between the Turks

28 On the broader context of Czech-German relations and identification in Bohemia at that time see Pieter M. Judson, The Habsburg Empire: A New History (Cambridge, MA: Harvard University Press / The Belknap Press, 2016), 292-99.

29 Tara Zahra, Kidnapped Souls: National Indifference and the Battle for Children in the Bohemian Lands, 1900-1948 (Ithaca, NY: Cornell University Press, 2008). See also Pieter M. Judson, Guardians of the Nation: Activists on the Language Frontiers of Imperial Austria (Cambridge, MA: Harvard University Press, 2006), 1-18.

30 Compare with the views of Austrians as described by Fichtner, Terror and Toleration, $21-72$. 
and the Czechs, but precisely because of this distance. They reveal how people construct Others irrespective of and sometimes especially in the absence of direct contact with them.

The Turks were not the most relevant Other for the Czechs in the early zoth century, nor did the Turks play a major role in the master narrative of Czech history. ${ }^{31}$ Nonetheless, Czech views of the Turks touch on and expose phenomena that transcend the framework of Czech history. Politically, the Czechs exemplify the response of a Central European people to the different and the unknown and their early-2oth-century attitudes can shed light on the persistence of stereotypes whose effects can be felt even today. When, in 2016, Czech politicians rejected the European Union's proposal to abolish visas for the Turks, they justified their position by citing human rights abuses in Turkey. The discussion in the Czech media, however, alluded to the Turkish wars and newspaper articles quoted Švejk's words about the Turks, which almost every Czech knows. ${ }^{32}$ The growing importance placed on relations between Europe and its neighbors in the 21st century makes it ever more important to better understand the different trajectories along which attitudes like this are constructed. People in Central or East-Central European countries are often at odds with the viewpoints espoused in what is commonly understood to be "Europe," especially with respect to attitudes toward immigrants and the Muslim world, but the sources of anti-immigration opinion in each country differ. ${ }^{33}$ The reactions of Central European peoples to non-European Others are usually interpreted as responses to a perceived threat, ${ }^{34}$ and an analysis of the way Czech views on the then most important "non-European" Others, the Turks, were

31 In the master narrative of Czech history, which well into the 2oth century was based on the work of František Palacký, the medieval Bohemian state was portrayed as the state of the Czech nation and the recurring encounters and confrontations with the Germans were identified as the defining feature of Czech history. For more on the Czech master narrative see Gernot Heiss et al., "Habsburg's Difficult Legacy: Comparing and Relating Austrian, Czech, Magyar and Slovak National Historical Master Narratives," in Contested Nation: Ethnicity, Class, Religion and Gender in National Histories, ed. Stefan Berger and Chris Lorenz (Houndmills: Palgrave Macmillan, 2008), 367-404.

32 "Máš rád Turky? Máš rád ty pohanské psy?," iDnes, February 26, 2016, accessed July 10, 2017, http://martinkavka.blog.idnes.cz/blog.aspx?c=496883.

33 See, e.g., "Special Eurobarometer 469: Integration of Immigrants in the European Union," accessed December 5, 2019, http://data.europa.eu/euodp/en/data/dataset/S2169_88_2_ 469_ENG.

34 On the differences between East European countries and for various explanations of East European attitudes toward Muslims see Alexander Yendell, "Understanding and Explaining Islamophobia in Eastern Europe," Connections: A Journal for Historians and Area Specialists (December 15, 2018), accessed December 5, 2019, https://www.connections.clioonline.net/article/id/artikel-4658. 
constructed in the late 19th and early 2oth centuries can add nuance to the explanation of these attitudes.

Analytically, the Czechs are an example of a large but understudied type of society that is seldom included in inquiries into the relationship between the West and the Muslim world: they were neither colonizers nor colonized; they were never under the Ottoman thumb, but had participated in wars with the Ottoman Empire and were close enough to the Turks for the latter to play a role in Czech culture and self-identification. In this respect, the Czechs were not unique. The Turks were a relevant but not the most important Other for large parts of Europe. Research on Czech attitudes to this Other may help broaden the range of approaches to exploring the relationship between the West and societies outside Europe, beyond the colonizer/colonized binary that still often dominates analyses of Europe's relations with the Muslim world.

This book tells two stories. It can be read from the perspective of European approaches to the Turkish and Muslim Others, and it is in this light that it presents Czech images of the "terrible Turk," the more nuanced views of travelers and scholars, and the Czechs' attitudes toward those whom some called "our Turks" - the Slavic Muslims of Bosnia-Herzegovina. But the book does more than provide a local variation on "the Turk in Europe" theme. It tells the story of an emancipating Czech nation who referred to the Turks in various ways while constructing Czech national identity within Europe, highlighting an understudied aspect of modern Czech history: as the Czechs searched for their place in Europe, they positioned themselves in relation to others whom they perceived to be inferior to them or in a less favorable situation. Distinguishing themselves from the Turks could be a way of demonstrating to themselves and to others how European they were, while what "Europe" actually meant was still being constructed. In this respect, the Turks were convenient Others, who were not central to emerging Czech national identity, but were salient enough to be employed toward various ends.

It has become a custom that any scholarship touching on Europe's attitudes to Muslim (and "Oriental") Others must adopt a position in relation to Said's "Orientalism," its later revisions, and critiques of it, even though there is an increasing feeling that Orientalism is a concept whose time has passed. According to some scholars, this is because Said got it mostly wrong in the first place. ${ }^{35}$ Others, while accepting the basic tenets of Said's arguments, either criticize some of his views or are convinced that scholarship has moved beyond "Orientalism," which has therefore lost its usefulness as an analytical concept.

35 See, e.g., Robert Irwin, Dangerous Knowledge: Orientalism and Its Discontents (Woodstock: Overlook Press, 2008), esp. $3^{-5}$. 
In the words of R. Stephen Humphreys, "at least within the guild of professional historians of Islam and the Middle East, 'Orientalism' is a very dead horse. It is time to stop beating it."36

This book is not meant as a polemic with Orientalism, and perhaps could have been written without reference to it. Nonetheless, as it deals with the period of "high Orientalism," the analysis can draw on the insights that can be derived from the debate Said's arguments continue to prompt. ${ }^{37}$ The Czechs, as we shall see, were inspired by "classic" Western Orientalism, but their attitudes shared some features of what Andre Gingrich has called "frontier" Orientalism, while they also differed both from its Austrian and Southeast European embodiments. ${ }^{38}$ However, rather than inventing a new sub-type, an idiosyncratic "Czech version of Orientalism," the book confirms that a variety of approaches to Muslim Others, specifically the Turks, existed in Europe. Edhem Eldem has argued that the Turks of the late Ottoman and early Republican period were viewed less "orientalistically" than other inhabitants of "the Orient" because they were better known to Europeans than other Muslims, and the Ottoman Empire was ethnically and religiously too diverse to enable simplified stereotyping. ${ }^{39}$ The Turks themselves, under the influence of Western Orientalism, created in the late 19th century their own version of Orientalism. "Ottoman Orientalism" is a term coined by Ussama Makdisi to denote the attitude of the Ottoman-Turkish rulers to the peripheries of the empire as it was undergoing a process of modernization. ${ }^{40}$ The imperial centre, Istanbul, was closer to the West than its peripheries, both temporally, as it had introduced

$36 \quad$ R. Stephen Humphreys, "The Historiography of the Modern Middle East: Transforming a Field of Study," in Middle East Historiographies: Narrating the Twentieth Century, ed. Israel Gershoni, Amy Singer, and Y. Hakan Erdem (Seattle: University of Washington Press, 2006), 31. Humphreys continues: "It is a word that is well on the way to losing whatever specificity and analytic value it once had, and it is now hardly more than a term of abuse for scholarship that one dislikes."

37 See François Pouillon and Jean-Claude Vatin, eds., After Orientalism: Critical Perspectives on Western Agency and Eastern Re-appropriations (Leiden: Brill, 2015).

38 See Gingrich, "Frontier Myths of Orientalism”; Bojan Baskar, "Ambivalent Dealings with an Imperial Past: The Habsburg Legacy and New Nationhood in ex-Yugoslavia," paper presented at the Institut für Ethnologie, Kultur- und Sozialanthropologie, Vienna, November 11,2003 .

39 Edhem Eldem, "The Ottoman Empire and Orientalism: An Awkward Relationship," in Pouillon and Vatin, After Orientalism, 89-9o. See also Edhem Eldem, "An Ottoman Traveler to the Orient: Osman Hamdi Bey," in The Poetics and Politics of Place: Ottoman Istanbul and British Orientalism, ed. Zeynep İnankur, Reina Lewis, and Mary Roberts (Istanbul: Pera Museum Publications, 2011), 183-95.

$40 \quad$ Ussama Makdisi, "Ottoman Orientalism," The American Historical Review 107, no. 3 (2002): 768-96. 
reforms earlier than the rest of the empire, and spatially. According to Makdisi, the strongest expression of an Orientalist attitude among the Ottoman-Turkish ruling elites was directed at the Arab provinces of the empire, and Ottoman Orientalism helped to justify Ottoman-Turkish rule over the as yet "unmodernized" Arabs. ${ }^{41}$ Eldem notes, though, that the Turks' view toward the Arabs, while based on a sense of Ottoman-Turkish superiority, was nevertheless influenced by the fact that the Arabs and the Turks shared the same religion, which made Ottoman Orientalism distinct from its European model(s).$^{42}$ The Czechs, like other Europeans, were of a different faith than the Turks and the Muslims of Bosnia and Herzegovina, but the dilemma they faced with respect to the Muslims of Bosnia-Herzegovina, who were Slavs like themselves, may have been similar to the one that the Turks experienced in their relationship to their Arab co-religionists. In other words, the Czechs might have regarded the Muslim Slavs in the same way that the Turks viewed the Arabs, as a people related to them, in this case by ethnicity rather than by religion, and as less advanced and waiting to be civilized.

One of the most common ways in which European perceptions of the Orient, Muslims and Ottoman Turks have been studied is through travel, because travel highlights how during encounters between two cultural systems concepts of cultural, ethnic, racial, and gender differences are constructed and perceived. ${ }^{33}$ Postcolonial studies, with their critique of European views on former colonies and their emphasis on the relationship between travel, the imperial project, and racial theories, have provided further impetus to the increasing

41 Makdisi makes the point that the Arabs on the peripheries of the empire were cast in an ambivalent role. They were seen at once as "members of an inferior 'minority' who were to be civilized, disciplined, and (ultimately, perhaps) fully integrated, and at the same time as markers of a foreign Orient, above which the modern empire was struggling so hard to rise." Makdisi, "Ottoman Orientalism," 794. Building on Makdisi's work, Selim Deringil sees the "civilizing mission" mentality of the late Ottomans as a result of the conflation of the ideas of modernity and colonialism and as a strategy of borrowing the colonialists' concepts and methods in order not to become a colony themselves. This "borrowed colonialism" led to a perception of their (predominantly Arab) peripheries as a "colonial setting" and targeted especially those elements of the empire which were considered unruly, savage, anti-modern, and hard to subjugate - the nomads. Selim Deringil, "'They Live in a State of Nomadism and Savagery': The Late Ottoman Empire and the PostColonial Debate," Comparative Studies in Society and History 45, no. 2 (2003): 311-42.

42 Eldem, "The Ottoman Empire and Orientalism," 96.

43 Tim Youngs, The Cambridge Introduction to Travel Writing (Cambridge: Cambridge University Press, 2013), 10. See also Sachidananda Mohanty, "Introduction: Beyond the Imperial Eye," in Travel Writing and the Empire, ed. Sachidananda Mohanty (New Delhi: Katha, 2003), IX-XXI. 
interest in travel writing. ${ }^{44}$ Rather than authentic, unbiased depictions of what the traveler saw, travel writing has been analyzed as a tool of imperial politics. ${ }^{45}$ The colonial context remains in the forefront of inquiries into modern travel literature, but other types of travels have started to be considered as well. ${ }^{46}$ In her analysis of travelers from East European peripheries to Western Europe, Wendy Bracewell pointed out that their travelogues were characterized by a different relationship between knowledge, representation, and power than is typical of Western travel writing. ${ }^{47}$ She noted that the real theme of the travelers' accounts was often their own country, not the country they were visiting, and that they sometimes adopted the perspective of Western travelers who evaluated East European countries from the point of view of their "Europeanness." 48 Even though Czechs' journeys into the Ottoman Empire were not undertaken with the same aims as East Europeans' travel to Western Europe, which Bracewell has analyzed, a question worth asking is whether Czech travelers shared some of the characteristics of other East European travelers that Bracewell points out in her analysis.

It seems obvious that there was a difference in the way Czechs traveled to the Ottoman Empire and the British to their colonies. The position of the Czechs as a non-ruling nation in the Austro-Hungarian Empire arguably absolved them of any connection with colonialism. Despite the rapid growth that Czech industrial, commercial and financial enterprises witnessed in the second half of the 19th century and especially at the turn of the century, the Czechs had limited economic and political interests in the Middle East. Economic advancement and the progress of the Czech national movement nevertheless had an effect on Czechs' expectations, and some of them started thinking about catching up with the more advanced Western nations by exporting Czech goods, skills, and capital. It thus makes sense to question the Czechs'

44 They have drawn attention to the fact that travel accounts are neither objective nor valuefree because even before setting out on their journey travelers were influenced by the cultural representations of the countries they were visiting and of the countries' inhabitants. See Youngs, The Cambridge Introduction to Travel Writing, 12-13.

45 Mary Louise Pratt argues that travel accounts are internally and necessarily connected with the act of colonization and understands them primarily as a part of the ideological aparatus of empires. Mary Louise Pratt, Imperial Eyes: Travel Writing and Transculturation (London: Routledge, 1992), 1-11.

46 See Wendy Bracewell and Alex Drace-Francis, eds., Under Eastern Eyes: A Comparative Introduction to East European Travel Writing on Europe (Budapest: Central European University Press, 2008).

47 Wendy Bracewell, "The Limits of Europe in East European Travel Writing," in Bracewell and Drace-Francis, Under Eastern Eyes, 66-67.

48 Bracewell, "The Limits of Europe," 101-10. 
alleged lack of colonial ambitions, whether or not these were directed toward the Ottoman Empire, and to inquire into whether their travel writing expressed a sense of belonging to Austria-Hungary and the interests of the empire.

In a special issue of National Identities devoted to the cultural components of colonialism the editors Barbara Lüthi, Francesca Falk, and Patricia Purtschert ask whether countries that were dependent on imperial powers should be considered colonies or contextualized within the European colonial metropolises. ${ }^{49}$ They pay attention also to countries that at first sight seem to have no colonial connections, such as Iceland or Switzerland, and they show the continued pervasiveness of colonial structures and power relations and their racializing effects. ${ }^{50}$ Lüthi, Falk, and Purtschert argue that representatives of countries without colonies reproduced the racialized, gendered, sexualized, and classed imagery prevalent in Europe, and by replicating the racist and dehumanizing standpoint they became aligned with the colonizers and took part in colonialism. ${ }^{51}$ Without denying that Czechs were as prone to racism as other nations in Europe, this book does not simply assume that their attitudes toward the Turks and other non-Europeans were driven by racism, but asks whether and how Czechs viewed the Turks in racial terms.

The question about colonial complicity is particularly relevant in analyses of the history of the academic fields known today as Middle Eastern and Turkish studies, ${ }^{52}$ inasmuch as in the West the emergence of the modern disciplines that deal with the Middle East coincided with the age of imperialism. ${ }^{53}$ Early Czech experts in the Middle East were undoubtedly influenced by the development of academic studies of "the Orient" in the West and by Western intellectual trends and schools of thought more generally, but their position differed from that of their Western counterparts in that there was no Czech state whose interests they could support through their scholarly undertakings. Therefore, if their works had purposes other than pure scholarship - and most Czech scholars wrote, for example, also popularizing literature - they cannot be automatically put in the

49 Barbara Lüthi, Francesca Falk, and Patricia Purtschert, "Colonialism without Colonies: Examining Blank Spaces in Colonial Studies," National Identities 18, no. 1 (2016): 1.

50 Ibid., 3 .

51 Ibid., 2. See also Sarah Lemmen, Tschechen auf Reisen: Repräsentationen der außeuropäischen Welt und nationale Identität in Ostmitteleuropa 1890-1938 (Cologne: Böhlau Verlag, 2018), 295-96.

52 The terminological issues of Oriental/Middle Eastern/Turkish Studies are addressed in Chapter Four ("Our Mission in Oriental Studies"), where the historiography on this subject is also discussed. On this historiography see, e.g., Gershoni, Singer, and Erdem, Middle East Historiographies.

See Humphreys, "The Historiography of the Modern Middle East," 22. 
same box as their British or Austrian counterparts. What, then, inspired their interest in the language, literature, and history of the Turks?

In general terms, the first generations of Czech experts in the Middle East in the late 19th and early 2oth centuries were motivated in their writing by an effort to advance and spread Czech culture, which included developing scholarly literature written in Czech. National concerns affected a large part of the intellectual and political activities of the Czech elites and "the nation" was for them one of the most relevant categories; hence the attention this book pays to Czech national awareness and the ways Czechs identified as Czechs and Slavs. This, however, should not imply that it looks at Czechs' views of the Turks through the prism of nationalism and solely within the framework of national history. Like Orientalism, though for very different reasons, "nationalism" is a concept that is criticized and considered to have run its course as a basis from which to analyze history, being replaced by various forms of non-national and transnational approaches, histoire croisée, Transfergeschichte, and entangled histories. ${ }^{54}$ Topics such as the ones addressed in this book cannot be studied and understood in isolation, within the confines of national history, whether it be comparisons with attitudes toward the Turks in other European countries, the movements of bodies across national borders in Europe and all the way to the Ottoman Empire, or the impact of ideas that were circulating internationally at that time. Conceptually, the book belongs to the strand of historiography that strives "to move beyond reductive national-historic and Eurocentric perspectives" and to point out trans-local, transnational, and transcultural associations in societies without colonies. ${ }^{55}$ Showing how Czechs in the late 19th and early 2oth centuries used images of the Turks when they were addressing contemporary issues of relevance to Czech society, the book sheds light on the darker side of Czech national discourse, touching on how it connects to racism, Orientalism, and xenophobia, and in this way it also tries to bring

54 For examples of this approach to Ottoman history see Firges et al., Well-Connected Domains. See also Michael Werner and Bénédicte Zimmermann, "Beyond Comparison: Histoire Croisée and the Challenge of Reflexivity," History and Theory 45 (2006): 30-50; Michael Werner and Bénédicte Zimmermann, "Vergleich, Transfer, Verflechtung: Der Ansatz der Histoire croisée und die Herausforderung des Transnationalen," Geschichte und Gesellschaft 28, no. 4 (2002): 607-36.

55 See Lüthi, Falk, and Purtschert, "Colonialism without Colonies," 2; Sönke Bauck and Thomas Maier, "Entangled History," InterAmerican Wiki: Terms - Concepts - Critical Perspectives, 2015, accessed September 18, 2018, https://www.uni-bielefeld.de/cias/wiki/e_ Entangled_History.html; Anna Amelina et al., eds., Beyond Methodological Nationalism: Research Methodologies for Cross-Border Studies (New York: Routledge, 2012). 
Czech history-writing, which is often overly self-absorbed, into the transnational field.

Describing various aspects of Czech national identification, the book moves from the political frame of Pan-Slavism, which defined the Czechs' renewed interest in the Turks in the 1870 , to images more in the cultural sphere as observed in the writings of travelers who visited the Ottoman Empire at the turn of the 19th and 2oth centuries. Next, the book looks at the more self-assured version of Czech nationalism that developed in the late 19th century and had its own implicit and occasionally explicit colonial ambitions. Finally, it examines the scholarly discourse and the validation of stereotypes by experts involved in the establishment of Czech Oriental studies, focusing on the Turks. In other words, the book is concerned with the political, cultural, scholarly, and colonial discourses that in some way touch on the Turks, rather than drawing on a clearly defined body of literature devoted to the Turks. It primarily analyzes non-fiction texts - travelogues, treatises, reference books, textbooks, histories, and other scholarly texts of the time - while it refers to literary works and popular writings intended for the amusement of the wider public solely as illustrations of the views expressed in these texts. ${ }^{56}$ Most of the authors of these works were intellectuals, scholars, and writers, well-known to and respected by the general audience, and they were often active in public life and able to influence public opinion. The analysis, however, does not try to trace how these views were received among the wider Czech audience; instead it focuses on the construction of the images of the Turks, looking at these images against the backdrop of broader European trends.

Images of the Other or Others (including the Turks) in the eyes of European nations are the subject of analyses in imagology, a specialism of comparative literature that studies cross-national perceptions and images expressed in literary discourse from a transnational point of view. ${ }^{57}$ Imagology is concerned with representations as textual strategies and as discourse. As Joep Leerssen explains, literary texts have a privileged position in imagology research because national stereotypes are articulated and disseminated first and with most

$5^{6}$ Translations of Western literature and popular trash literature, which undoubtedly influenced Czech readers, are left aside here; although they could contribute to or even alter some of the arguments presented here, to discuss them would require a separate analysis (and another book).

57 Joep Leerssen, "Imagology: On Using Ethnicity to Make Sense of the World," in "Les stéréotypes dans la construction des identités nationales depuis une perspective transnationale," ed. Géraldine Galéote, special issue, Iberic@l, no. 10 (2016): 13-31. 
effect in poetical texts. ${ }^{58}$ Although this book does not examine the Czechs' views of the Turks from the perspective of comparative literature ${ }^{59}$ and is not foremost focused on literary texts, it shares some of the key premises of imagology studies, especially the assumption that images of Others are constructed by texts and are used to explain the Others' behavior. The processes whereby stereotypes of Others are constructed in non-fiction resemble those in literary texts, but while a fictional character always possesses more attributes than just ethnicity, ${ }^{60}$ the sources analyzed in this book often view the Other as an undifferentied whole (with the exception of writing that deals with women).

Representations of Others change over time, partly in response to developments within the field of literature, but also to political and social circumstances. Nedret Kuran-Burçoğlu has summed up the evolution of "the image of the Turk" that emerged in the Western world in the 11th century and divided it into three distinct stages: In the early period of Ottoman expansion, up until the late 17th century, the image of the Turk was that of an alien, cruel, and tyrannical Muslim Other. In the next stage, which in Western Europe coincides with the decline of Ottoman power, the spread of Enlightenment thought, and an increasing interest in the exotic Orient, the images became less Turkophobic. Finally, the proclamation of the Turkish Republic in 1923 resulted in a

$5^{8}$ Joep Leerssen, "Imagology: History and Method," in Imagology: The Cultural Construction and Literary Representation of National Characters; A Critical Survey, ed. Manfred Beller and Joep Leerssen (Amsterdam: Rodopi, 2007), 27. According to Leerssen, "images do not reflect identities, but constitute possible identifications."

59 Imagology approaches are considered useful, for instance, in international relations, cultural history, and the study of national policy and national character. See Daniel-Henri Pageaux, "La péninsule ibérique et l'Europe: Ouvertures, fermetures, dérives," in Komparatistik und Europaforschung: Perspektiven vergleichender Literatur- und Kulturwissenschaft, ed. Hugo Dyserinck and Karl Ulrich Syndram (Bonn: Bouvier Verlag, 1992), 253; Davor Dukić, "The Concept of Cultural Imagery: Imagology with and not against the Early Völkerpsychologie," in Discontinuities and Displacements: Studies in Comparative Literature; Proceedings of the XVIII. Congress of the ICLA, ed. E.F. Coutinho (Rio de Janeiro: Aeroplano, 2009), 78. In the introduction to the Imagology handbook, Manfred Beller states that it is based on a variety of methodological approaches, whose main aim is to analyze the origin and function of the images of a foreign and one's own nation. See Manfred Beller, "Perception, Image, Imagology," in Beller and Leerssen, Imagology, 13. See also Hugo Dyserinck, "Komparatistik als Europaforschung," in Dyserinck and Syndram, Komparatistik und Europaforschung, 37; and Leerssen, "Imagology: History and Method," 1732. Leerssen, who has focused on the methodology of studying national character, stresses that in modern times, nations view their character and individuality namely in those aspects in which they differ most from others. Joep Leerssen, "The Poetics and Anthropology of National Character (1500-200o)," in Beller and Leerssen, Imagology, 69 .

Leerssen, "Imagology: On Using Ethnicity," 26. 
partial separation of the image of the Turk from the stereotypes of the Ottoman past. ${ }^{61}$ Kuran-Burçoğlu notes that in the second period or stage the image of "the Turk" started to move in a different direction in Southeastern Europe, where "Ottoman rule continued to inspire strong national enmity and where earlier practices (such as the enlisting of Christian boys and girls for the janissary troops and harems, or cruel modes of corporal punishment) gained mythical proportions and cast the Turks into the very opposite of Christian familial values." ${ }^{2}$ In a more detailed study of the evolution of "the image of the Turk" in Europe from the 15th to the 21st century, Kuran-Burçoğlu distinguished no less than eight stages in its development. According to her, the sixth stage was marked by a shift toward more positive imagery in German-speaking regions due to the influence of the Enlightenment, and the seventh stage saw the emergence of a variety of images in individual European countries over the course of the 18 th and 19 th centuries. ${ }^{63}$

Other authors have examined the differences in how the Turks were viewed within one region. Mustafa Soykut, for instance, contends that from the Renaissance to the 17th century the image of the Turk in Venice, which had important political and commercial contacts with the Ottoman Empire, differed from images that prevailed in the rest of Italy and specifically from Rome as the primary source of Catholic anti-Turkish rhetoric. ${ }^{64}$ Davor Dukić in his detailed analysis of the images of the Turks in early modern Croatian literature, Sultanova djeca (Children of the Sultan), ${ }^{65}$ explored the specific features of images connected with the Turks that appeared in different literary genres and how they changed both over time and across regions which had different relations with the Ottoman Empire. ${ }^{66}$ Dukić shows that at first these images were

61 Nedret Kuran-Burçoğlu, "Turkey," in Beller and Leerssen, Imagology, 254-55.

62 Kuran-Burçoğlu, "Turkey," 255.

63 Nedret Kuran-Burçoğlu, "A Glimpse at Various Stages of the Evolution of the Image of the Turk in Europe: 15th to 21st Centuries," in Soykut, Historical Image of the Turk, 24. According to the author, 19th-century paintings representing the Turks associated them with mystery and wealth, sensuality and sexual freedom for men, beautiful women, laziness, idleness, and a relaxed atmosphere, a lack of discipline, and a slight backwardness. KuranBurçoğlu, "A Glimpse," 3 .

64 Mustafa Soykut, "The 'Turk' as the 'Great Enemy of European Civilisation' and the Changing Image in the Aftermath of the Second Siege of Vienna (In the Light of Italian Political Literature)," in Soykut, Historical Image of the Turk, 45-116, esp. 55.

65 Davor Dukić, Sultanova djeca: Predodžbe Turaka u hrvatskoj književnosti ranog novovjekovlja (Zagreb: Thema, 2004).

66 The author points out the differences between the Ottoman vassal Dubrovnik (Ragusa), Dalmatia along with Venice, which was often at war with the Ottoman Empire, central Croatia, which was furthest from the Turkish threat, and Slavonia, which was under Ottoman rule from the 16 th to the end of the $17^{\text {th }}$ century. 
expressions of fear and the need to mobilize against an enemy, but they later also reflected an interest in the culture and way of life of the new neighbor with whom the Croats now lived and did business; this interest even led to occasional expressions of tolerance of the Turks.

Works dealing with images of the Turks ${ }^{67}$ have tended to pay more attention to several European regions that were of particular relevance with respect to this imagery: the regions of Italy, where there were various responses to the Muslim Turks in the early modern period; Southeastern Europe, where both daily experience and literature offered steady reminders of the Turkish presence there; and the parts of Western Europe where writings emerged that especially from the Enlightenment period onward had an undeniable impact on literary representations produced on the rest of the continent. This focus, although understandable, leaves a lot of blank spots on the map of Europe. Without further study, the opinions and imagery in other countries can only be seen as expressing some general trends or be subsumed within one of the two main types distinguished by Kuran-Burçoğlu - the West or Southeastern Europe. For the Czechs, however, the Ottoman practice of supplying the janissary corps or their harems with Christians did not gain the kind of "mythical proportions" it assumed in the areas of Southeastern Europe under Ottoman rule, nor was the Ottoman Empire ever the subject of fundamental reassessment in the Enlightenment era as it was in the West. ${ }^{68}$

Another possible framework in which Czech images of the Turks can be analyzed is the context of Central, or East-Central, Europe. Although the region that today comprises the Czech, Slovak, Hungarian, and Polish states is perceived as relatively uniform largely because of its communist past, the Czech lands shared with other non-Austrian areas of Central Europe two features that are relevant for the way in which Turks were viewed in the 19th and early 2oth centuries: first, they had faced the imminent threat of Turkish occupation and for centuries their population had participated in wars against the Turks, and second, they were dominated by the Habsburgs (in the case of the Poles part of the territory was) - and this was during a period that was important for the construction of national identities and histories. In other respects, the situation of the four Central European nations differed. While parts of Hungary, including both the Magyar- and Slovak-speaking populations, were under direct Ottoman rule, Poles fought and coexisted with Ottoman Turks and Crimean Tatars, and the Czech lands were for the most part separated from Ottoman territories by their neighbors. The Czech, Slovak, and

67 See, e.g., the edited volumes Imagining "the Turk" and Historical Image of the Turk.

68 Kuran-Burçoğlu, "Turkey," 255. 
Polish populations were all Slavic, and this allegiance grew in importance during the 19th century. The Hungarians (or Magyars) ${ }^{69}$ differed from their Slavic and German-speaking neighbors and their 19th-century search for national identity gave rise to a theory about the common origins of Hungarians and Turks.

Individual national historiographies do not approach the period of the Turkish wars and the times in which the country was in close contact with the Ottoman Empire in the same way. Mainstream Slovak historiography has traditionally referred to Ottoman rule as the "Turkish yoke" - which is how Turkish power is often described in the histories written in the areas it dominated. The depiction of Ottoman rule in Slovak historiography is not entirely negative: the Ottomans' occupation of large parts of Hungary and southern Slovakia temporarily made the Slovak regions that remained free the economic, political, and cultural center of Hungary, whereby they became much more important. ${ }^{70}$ Yet, popular, non-scholarly works today still often employ the kind of emotional language that was typical of 19th-century discourse, where "the Turk" is used as a synonym for cruelty or something evil. ${ }^{71}$ Slovak relations with the Turks and images of the Orient are only rarely the subject of theorizing. One notable exception is Charles Sabatos's comparative study of Czech, Slovak, and Hungarian literary images of the Turks, which argues that Slovak literature is more remote from Said's Orientalist paradigm than the other two because Slovaks were not in a position of power, either in relation to the Turks or within the Habsburg Empire. ${ }^{72}$

In contrast to Slovak historiography, Hungarian and Polish historians point to the importance of the Orient in their own country's national selfidentification. Hungarian historians explain Hungarian intellectuals' interest

69 Although Hungary and Hungarian can refer to the territory and administrative unit within the Habsburg Empire inhabited by people of different ethnic origins, including the Magyars, in English Magyar and Hungarian are used as equivalents. This book also uses both terms as interchangeable, often depending on the sources that are being described.

70 A major recent historical work, for instance, speaks of the "unpleasant neighborhood of the Ottoman Empire with all the negative and positive [aspects] resulting from this coexistence." See Viliam Čičaj, "Úvod," in Turci v Uhorsku, vol. 1, Život v Uhorskom královstve počas tureckých vojen od tragickej bitky pri Moháči až do Bratislavského snemu (Bratislava: Literárne informačné centrum, 2005), 13.

71 See, e.g., Ján Mäsiar, Turecká podkova: Dedičstvo tureckých čias v Honte a Novohrade (Martin: Vydavatel'stvo Matice slovenskej, 2014), 6.

72 Charles D. Sabatos, Mitve Tarih Arasında: Orta Avrupa Edebiyat Tarihinde Türk Imgesi (Istanbul: Bilge Kültür Sanat Yayın Dağıtım San. ve Tic. Ltd. Şti, 2014), 16; Charles D. Sabatos, Frontier Orientalism and the Turkish Image in Central European Literature (Lanham: Lexington Books, 2020), XIX. 
in the Orient, or Asia, in the early 19th century as a part of the construction of national identity and the search for the nation's roots, and they show that Hungarians in the 19th century were ambivalent about the Turks. Ildikó BellérHann contends that this ambivalence derived, on the one hand, from the history of the Turkish wars and Ottoman occupation, resulting in the Hungarians' perception of themselves as a "bastion of Christendom" against the Turks, and, on the other hand, from the 19th-century myth about the shared roots of the Hungarians and the Turks and from the awareness that the Ottoman Empire had served as a safe haven for famous Hungarian revolutionaries, owing of which the Turks were seen as relatives or friends. ${ }^{73}$ Margit Köves has explored how images of the Orient in Hungarian literature and intellectual life changed over time: while in the first half of the 19th century they were used to emphasize how the Hungarians were a unique people within Europe and thus served the nation-building project, in the second half of the century they helped to present Hungarian identity as both Oriental and Western at once. ${ }^{74}$

In Poland, self-orientalization followed a different path. According to Jan Reychman, the prominent Polish Turkologist, in early modern times close contact between the Polish-Lithuanian Commonwealth and the Ottoman Turks and the Tatars led to the appearance of strong Oriental influences in Poland directly received from the East. Then in the 18th century elements of Oriental culture reached Poland through Enlightenment thought that spread from Western Europe. On Polish territory, these Oriental elements underwent significant transformations and were affected by the image of the Orient that had formed in earlier times. The resulting synthesis was, in Reychman's words, "creative."75 Jan Kieniewicz, whose views are often quoted by historians studying Polish Orientalism, ${ }^{76}$ argued that Poland, unlike other countries, was characterized by an "Orientalness" and that "Poland was certainly closer to the Asiatic East in the 16th century than any other European country, including Portugal. She understood and appreciated the East..."77 He described how the attitudes and

73 Ildikó Bellér-Hann, "The Turks in Nineteenth-Century Hungarian Literature," Journal of Mediterranean Studies 5, no. 2 (1995): 225-26.

74 Margit Köves, "Modes of Orientalism in Hungarian Letters and Learning of the Nineteenth and Twentieth Centuries," in Deploying Orientalism in Culture and History: From Germany to Central and Eastern Europe, ed. James Hodkinson et al. (Rochester, NY: Camden House, 2013), 166.

75 Jan Reychman, Orient w kulturze polskiego oświecenia (Wrocław: Zakład Narodowy imienia Ossolińskich, 1964), esp. 7 and 359.

76 See, e.g., Karolina Rak, "The Story of Polish 'Orientalness' - Researching Islam in Poland," UNNES International Conference on Research Innovation and Commercialization 2018: KnE Social Sciences 3 (2018): 716-22, doi: 10.18502/kss.v3i18.4761.

Jan Kieniewicz, "Polish Orientalness," Acta Poloniae Historica 49 (1984): 79. 
values adopted by the Polish gentry in the 17 th century became intertwined with Western influences in a unique Polish synthesis. This Orientalness made it possible for the Polish gentry not to have to choose between the East and the West, whereas the Oriental influences that came through the West in the 18th century became a source of internal conflict in Poland. ${ }^{78}$ In the 19th century, according to Kieniewicz, the Poles' bifurcated attitude toward the Orient had other sources as well: A number of well-known Poles immigrated to the Ottoman Empire, which cast the Orient in a positive light, but the Poles' views were even more importantly determined by their animosity toward Russia, which occupied a part of Poland. Because Russia was regarded as Asiatic, i.e. Oriental, the Poles saw themselves as the bulwark of Western Christianity and an outpost of Europe. ${ }^{79}$

Early modern Czech images of "the Turk" based on religious antagonism did not particularly differ from the notions prevalent in most of Christian Europe. With the decline of Ottoman military power and the emergence of the Czech national movement the Turkish threat gradually lost importance in Czech imagery. As Czech memory of the wars faded, the picture of "the Turk" as a fierce and cruel fighter and archenemy of Christianity lost its salience. The first chapter of this book, "The Return of the "Terrible Turk," shows how, just as these developments induced a transition to a secular and more neutral view of the Turks, the events in the Ottoman Balkans resuscitated older, negative stereotypes. Examining non-fiction writings that reacted to the suppression of the $1870 s$ uprisings of the Southeast European Slavs, the chapter reflects on the role religious, national, and racial concerns played in Czech views of the Turks.

The number of Czechs who in the late 19th century had personal experience with Ottoman Turks, while rising, was still rather limited. Chapter Two, "Czechs Abroad," looks at the travel writings of the Czechs who traveled to the Ottoman Empire and former parts of it and who were thus able to provide what was considered a true account of the character and life of the Turks. Although a first-hand encounter with the Ottoman Empire and its inhabitants had the potential to modify the views of Czech travelers, and some of them indeed expressed sympathy for the Turks and Islam, they did not regard the local population as their equals. The chapter asks on what grounds the Czechs based their feeling of superiority over the Turks and how the journey reflected and affected the travelers' own identification as Czechs, as citizens of the AustroHungarian Empire, and as Europeans. It situates Czech travel writing in the framework of European travel literature on the Ottoman Empire and inquires

$78 \quad$ Ibid., $85^{-90 .}$

79 Ibid., esp. 95-101. 
into whether and how Czech travels differed from their West and East European counterparts.

The Ottoman Empire was not the only space in which Czechs encountered "Turks," or what they thought were Turks. After the Austro-Hungarian occupation of Bosnia-Herzegovina in 1878, many Czechs visited the former Ottoman provinces whose population included a large Muslim community whom the Czechs referred to as "Turks." Compared to the German-speakers of AustriaHungary, ${ }^{80}$ the Czechs' relationship to the Muslims of Bosnia-Herzegovina was complicated by the fact that most of these Muslims were Slavs, with whom the Czechs felt a kinship-like affinity. In view of the essentially secular nature of Czech nationalism, the third chapter, "Civilizing the Slavic Muslims of BosniaHerzegovina," examines to what extent it mattered that these Slavs were of a different religion. Although not all the Czechs who settled in, worked for, or traveled to Bosnia and Herzegovina were in the service of the state, their presence in the provinces was underpinned by the fact that Bosnia-Herzegovina was controlled by the Austro-Hungarian Empire. The chapter asks how this fact influenced the way Czechs viewed the Slavic Muslims and whether they identified with the empire that backed their presence in the provinces.

While encounters with the Turks in the Ottoman Empire and "the Turks" in Bosnia-Herzegovina gave visitors the opportunity to confront their pre-existing stereotypes of the Turks with personal observations, scholarly writing fleshed out the image of the Turks with information and explanations based on expert knowledge. The fourth chapter, "Our Mission in Oriental Studies," focuses on the emerging field of study of the Turkish language, literature, and history in the late 19th and early 2oth centuries, which had initially been encompassed within scholarship on the Middle East or even "the Orient" more broadly. Since Czech intellectuals were in the late 19th century deeply concerned with national issues and there were no obvious impulses for research on the Ottoman Empire in Czech society to develop, the chapter seeks to identify the motives for a professional interest in the Turks. It explores the factors that structured the scholars' writings, embedding Czech academics' work on the Turks into international scholarship on the one hand and the opinions of the "lay" Czech public on the other.

Jaroslav Hašek's popular literary hero the Good Soldier Švejk claimed that the Austrian Archduke Franz Ferdinand was killed by the Turks ("because of Bosnia and Herzegovina"), and that the Austrian emperor would undoubtedly respond by declaring war. "War is certain. Serbia and Russia will help us in it. There won't half be a blood bath," he argued. "It may be,' he said, continuing his

8o See Gingrich, "Frontier Myths of Orientalism," 106-11. 
account of Austria's future, 'that if we have war with the Turks the Germans'll attack us, because the Germans and the Turks stick together. You can't find bigger bastards anywhere." 81 Hašek thus brings together the two Others whom the Czechs had since the early modern period (though in very different ways) been using to define their identity. The war that indeed followed the attack in Sarajevo led to the dissolution of both the Ottoman and Austro-Hungarian Empires, creating a new constellation of international relations. In these new circumstances the Czechs had to find their place in Europe again. The concluding chapter, "The New Republics," summarizes Czech views of the Turks described in the previous chapters and briefly outlines how they changed after the independent Czechoslovak state and the Turkish Republic were established.

$81 \quad$ Hašek, The Good Soldier Švejk, 12. 